
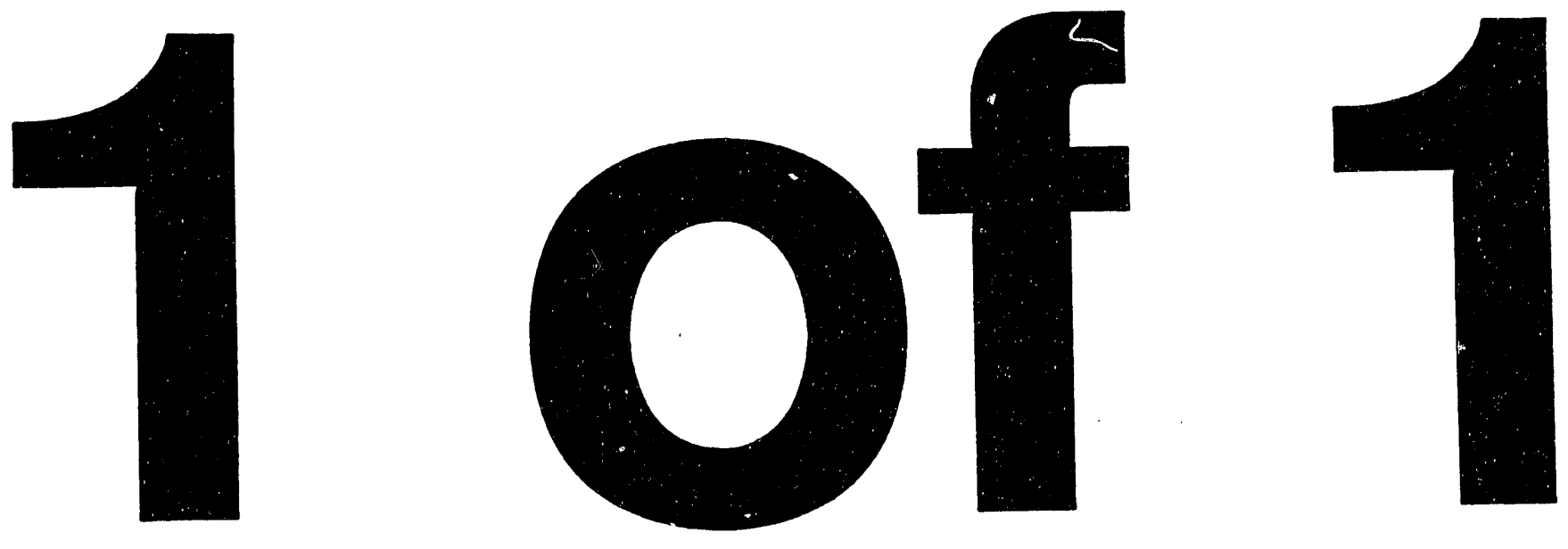
Title:

SUBSURFACE FRACTURE MAPPING USING MTCROEARTHQUARES DETECTED DURING PRTMARY OIL PRODUCTION, CLINTON COUNTY, KENTUCKY

\section{Submitted to:}

JAMES T. RUTLEDGE

W. SCOTT PHILLIPS

ADAM ROFF

JAMES N. ALBRIGHT

TERENCE HAMILTON-SMITH

STEVEN R. JONES

KARL C. RIMMICH

SOCIETY OF PETROLEUM ENGINEERS

69TH ANNUAL TECHNICAL CONFERENCE AND EXHIBITION

NEW ORLEANS

LA SEPTEMBER 25-28, 1994

\section{Los Alamos}

NATIONAL LABORATORY

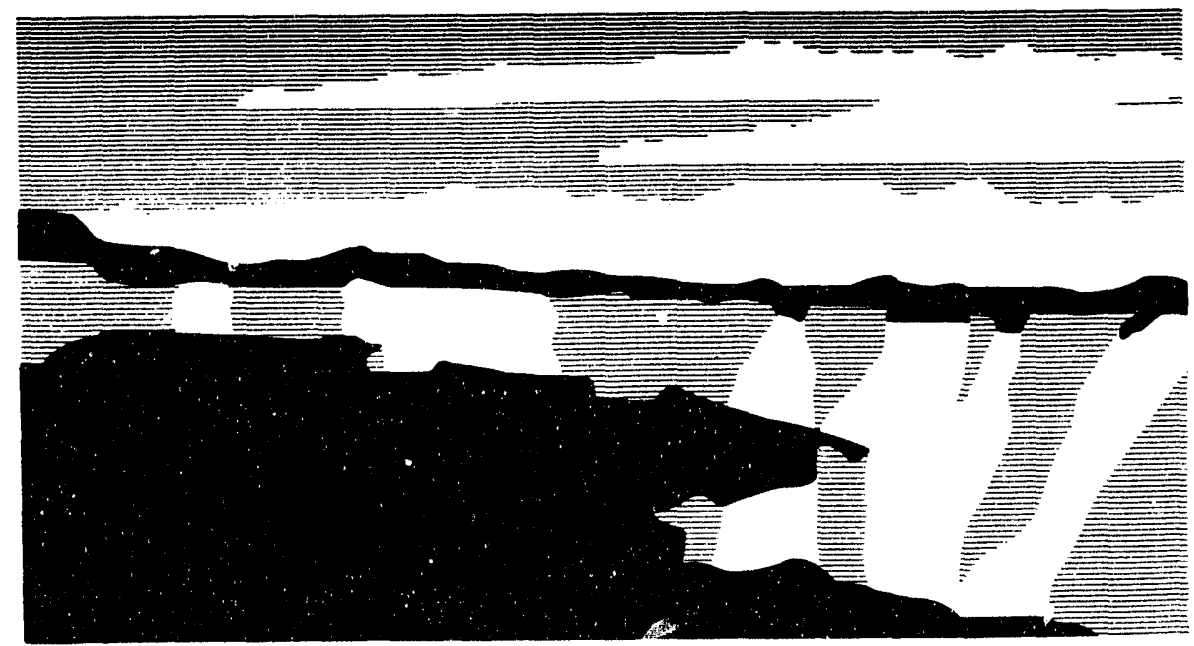

Los Alamos National Laboratory, an affirmative action/equal opportunity employer, is operated by the University of California for the U.S. Department of Energy under contract W-7405-ENG-36. By acceprance of this article, the publisher recognizes that the U.S. Government retains a nonexclusive, royalty-free license to publish or reproduce the pubished form of this contribution, or to allow others to do so, for U.S. Government purposes. The Los Alamos National Laboratory requests that the publisher identify this article as work performed under the auspices of the U.S. Department of Energy. Dromisution of THIS OUCUMENT is URILIMITED 


\title{
Subsurface Fracture Mapping Using Microearthquakes Detected During Primary Oil Production, Clinton County, Kentucky
}

\author{
James T. Rutledge and W. Scott Phillips, Nambe Geophysical, Inc.; Adam Roff and James N.
} Albright, Los Alamos National Laboratory; Terence Hamilton-Smith, Kentucky Geological Survey; Steven K. Jones and Karl C. Kimmich," Meridian Exploration Corp.

\begin{abstract}
'SPE Member
This peper was proparod for presentation at the 69th Annual Technical Conference und Exhibition of the Socidy of Pearoleum Enginears hald in New Otleans, LA, September 25-23, 1994.

This paper was selected for prosentution by an SPE Proeram Committee following review of information contained in an abetract submitted by the euthor(s). Contents of the paper, as presented, have not been reviewad by the Society of Petroleum Engineers and are subject to carrection by the author(s). The material, as presented, does noe

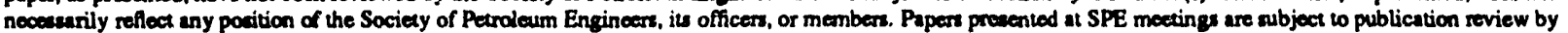

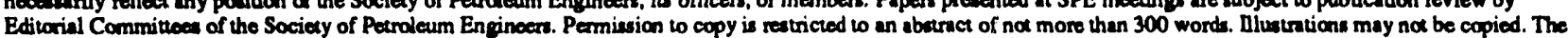
abatract thould comein conpicuous acknowled gment of where and by whom the paper is presented. Write Librarian, SPE, P.O. Box 833836, Richardacn, TX 75083-3836
\end{abstract} U.S.A. Telex, 730989 SPEDAL.

\begin{abstract}
Downhole microseismic monitoring tests were conducted in Clinton County, Kentucky to determine if microearthquakes associated with primary production could be detected on a scale of interwell distances $(2400$ $\mathrm{ft}$ ) and to determine if such microearthquakes could be used to map reservoir fractures. The oil reservoirs occur in shallow (750 to $2400 \mathrm{ft}$ ), low-porosity (<2\%), carbonate rocks of Ordovician age. The reservoir fracture system controlling the occurrence and flow of oil and its relationship to the local and regional geology is poorly understood. Discrete reservoir microearthquakes were detected at an average rate of 11 events per week and at distances up to $4000 \mathrm{ft}$ in an initial monitoring test using a single, triaxial downhole geophone receiver. In a second monitoring test 2 downhole, triaxial geophone tools were placed in a monitor well $800 \mathrm{ft}$ from a new, high-volume oil well. Over a 6-month period of continuous monitoring 165 discrete, high-quality, microearthquake waveforms were recorded. Approximately 11,000 barrels of fluid were extracted in the monitor area during the 6-month period. Presently, it is unknown whether or not the microseismicity is induced by production. Hypocenters computed for 121 events delineate 4 extensive (up to 0.15 squaremiles), low-angle, planar features striking approximately
\end{abstract}

$\mathrm{N} 65^{\circ} \mathrm{E}$ within the Ordovician reservoir depth interval. A composite fault-plane solution indicates a thrust focal mechanism. Such thrust structures are not observed in the surface-exposed Mississippian section, which lies above and is separated from the Ordovician section by a major unconformity of Devonian age. General relationships between the fractures revealed by the microseismicity and oil occurrence have yet to be demonstrated in the study area. The observed microseismicity occurs away from production wells, and to date, no new wells have been drilled into the mapped fractures along which shear displacement was detected.

\section{Introduction}

Significant potential for high-volume oil production has been demonstrated by recent discoveries from shallow, fractured, carbonate reservoirs in Clinton County, Kentucky. ${ }^{1}$ The nature of the fracture system controlling the occurrence and flow of oil and its relationship to the local and regional geology, however, is poorly understood. Clinton County is located in south-central Kentucky and lies on the eastern flank of the Cincinnati Arch separating the Appalachian basin to the east from the Illinois basin to the west (Figure 1). The Paleozoic section is divided into three major stratigraphic sequences by two regional

References and illustrations at end of paper. 
unconformities (Figure 2). A major unconformity at the top of the Knox Group marks the simultaneous effects of the Taconic orogeny and eustatic sea-level fall during the middle Ordovician. ${ }^{2}$ Another regional unconformity of Devonian age, at the base of the Chattanooga shale, marks the effects of the Acadian orogeny. 3,4 Low-amplitude structures in the surface-exposed Mississippian section were formed during the Alleghanian orogeny of Permian age.

Oil production in Clinton County, Kentucky is from very low porosity $(<2 \%)$, fractured, carbonate rocks of Ordovician age, including the Lexington Limestone, High Bridge Group, Wells Creek Dolomite and Knox Group, at relatively shallow depths ranging from 750 to $2400 \mathrm{ft}$ (Figure 2). Recent high-volume discovery wells in the area have produced from the upper part of the middleOrdovician High Bridge Group (equivalent to the Stones River Group of Tennessee). ${ }^{1}$ The High Bridge Group consists mainly of argillaceous limestone, and was deposited in a shallow-marine to tidal-flat environment. ${ }^{5}$ Production from well to well varies widely and is assumed to result from fracture control of oil occurrence and permeability. Typical wells in the area produce about 2 barrels (bbls) of oil per day or less. Fracture production is suggested by some high-volume wells with initial production rates as high as 400 bbls per hour and sustained rates of 100 to 250 bbls per day.

Finding the fractures that control the occurrence and flow of oil in the Ordovician section appears to be the key to drilling a successful high-volume well. Despite the shallow depths, the success rates of wildcat and even step-out wells in the area has been low. Conventional geological data available in the area have not provided any useful information on the location or orientation of reservoir fractures. Regional structures in the middle-Ordovician section tend to reflect regional gravity and magnetic anomaly maps suggesting basement control of structures in the Ordovician section. Structures in the near-surface Mississippian section, deposited subsequent to the Acadian orogeny (Devonian), are distinctly different. Inference of structures in the Ordovician aged reservoirs from the surface geology, therefore, may not be warranted ${ }^{1}$.

In other areas, detecting and locating microearthquakes induced during hydraulic fracture operations has been successfully used in mapping conductive reservoir fractures opened up during injection operations. ${ }^{6}$ Triggered seismicity has also been associated with stress changes accompanying fluid extraction, but the association between the induced seismicity and fluid-flow paths is much less direct. ${ }^{7}$ We have conducted tests in Clinton County to determine if reservoir micrnseismicity, detectable on the scale of interwell distances, cccurs during primary oil production from new, high-volune wells. The test results have been positive, and indicate that the reservoir microseismicity may be useful in delineating reservoir fractures in the vicinity of high-volume wells.

\section{Initial Monitoring Test}

An initial test was conducted during the winter and spring of 1993 to determine if reservoir microseismicity could be detected during new, primary oil production. A single 3component, borehole geophone tool was deployed in well $\mathrm{M}, 400 \mathrm{ft}$ north of well FS1 (Figure1). At the time, well FS1 was a new, isolated discovery well. Well FS1 produced from the upper part of the High Bridge Group at a depth of approximately $1000 \mathrm{ft}$. The geophone tool was placed at $1100 \mathrm{ft}$ depth, within the High Bridge Group. Over a 10-week period of continuous monitoring, 110 shear-slip type microearthquakes were detected (e.g. Figure 3). Events were detected up to $4000 \mathrm{ft}$ from the monitor well. Most events detected occurred within $200 \mathrm{ft}$. Figure 4 shows the daily production andi event detection count. A cumulative volume of 10,300 tarrel's (bbls) of fluid (100\% oil) had been produced from FS! by the time monitoring ended and $51 \%$ of this volume was extracted during the first 9 days of production in late-December, 1992, 6 weeks before monitoring began (Figure 4). Relationships between the microseismic event occurrence and temporal fluctuations in production are not evident. The in-situ stress field and induced stress changes resulting from the fluid extraction are not known. Neither are background microseismicity levels prior to production known. However, linear/planar features revealed by the locations of the microearthquakes implied that discrete shear slip was occurring along fractures within the reservoir interval and that the microseismicity, whether natural or induced, was useful in delineating reservoir fractures at large distances from the monitor well.

\section{Two-Station Monitoring}

In late August, 1993 a second producing well, FS2, located $800 \mathrm{ft}$ northeast of the monitor well $\mathrm{M}$ was completed (Figure 1). Three weeks later, we reoccupied well $\mathrm{M}$ by deploying two borehole, 3-component geophone tools at 500 and $1100 \mathrm{ft}$ depth. Results from the analyses of the data collected with the 2-geophone deployment are presented in this paper. The tools were equipped with 3 
orthogonal, $8 \mathrm{~Hz}$ (deep tool) and $30 \mathrm{~Hz}$ (shallow tool) geophone components. A mechanical arm couples each instrument to the borehole wall. The analog geophone outputs are amplified $60 \mathrm{~dB}$ downhole before transmission uphole. At the surface the data signals are further amplified and anti-alias filtered before input to a digital, PC-based, data acquisition system. The PC stores discrete signals captured by an algorithm which triggers on signal levels of a specified amplitude over a continuously-measured background level. The digital sample interval was $0.2 \mathrm{msec}$ per channel.

\section{Mapping Microearthquakes with Two Receivers}

Over a 6 month monitoring period, from September 16, 1993 to February 10, 1994, 196 microearthquakes were detected on both instruments. Of the 196 events, 165 had clear P-and S-wave arrivals that could be identified on both instruments (e.g. Figure 5). The hypocenter locations were determined in 2 separate steps. In the first step a radial distance and depth from the monitor wellhead were computed using the traveltime data alone. Depth, radial distance and origin time were determined using a standard, iterative computation in which the difference between the predicted and observed data are minimized. An initial location was computed assuming straight ray paths from source to receivers in a homogeneous medium. Subsequent locations were computed by ray tracing through a 2-dimensional, layered, P-wave velocity structure determined from nearby sonic logs (Figure 2). An average ratio of $\mathrm{P}$-wave velocity over $\mathrm{S}$-wave velocity ( $\mathrm{Vp} / \mathrm{Vs}$ ) equal to 1.9 was determined from a downhole calibration shot detonated in well MF2 at $1218 \mathrm{ft}$ depth (Figure 1). Onset arrival qualities of both P- and S-waves were, in general, very impulsive. Estimated errors in the arrival-time picks are $0.5 \mathrm{msec}$ or less. Computed locations were discarded if the final $\mathrm{ms}$ traveltime residuals between data and predicted arrival times were greater than $1.0 \mathrm{msec}$.

A unique azimuth with respect to the monitor well $M$ was then determined for each event using the P-wave particle motions recorded on both instruments. The trajectory from a single receiver to a source, in a homogeneous medium, can be measured as the principal axis of an ellipsoid fitted to the 3-dimensional particle motion. ${ }^{8}$ With only one receiver there is a 180 degree ambiguity in the trajectories, since it not known whether the direction corresponds to a compressional first arrival from the indicated direction or a dilational first arrival from the opposite direction. We resolved the ambiguity using the polarities and particle motions recorded on the upper tool.
The traveltime-computed depths indicated that all events occurred below the upper tool. The correct azimuth to the event source was therefore taken as the azimuth corresponding to the downward trajectory on the upper geophone tool. The actual azimuth was computed from the 2 horizontal components of the lower tool which in general had higher signal-to-noise ratios than the upper tool. Trajectories computed from the upper tool data were only used to resolve the ambiguity in azimuthal trajectories of the lower tool data.

Determining the geographic orientation of each tools' horizontal axes was accomplished by detonating small charges ( $20 \mathrm{ft}$ of 100 grain prima-cord) in shallow hole (about 4 to $5 \mathrm{ft}$ depth) offset $800 \mathrm{ft}$ from the monitor well M. Figure 6 shows the particle motion projection for the horizontal components of the lower tool from one of the orientation shots. A $2.0 \mathrm{msec}$ window of P-wave data was used to compute the particle motion trajectories of the microearthquakes. The window width is minimized to avoid any tool resonances and secondary arrivals. Azimuthal trajectories were considered well constrained if the ratio of the principal axis of the ellipse, obtained by eigenvector analysis, ${ }^{8}$ over the sum of both axes exceeded 0.85 . A perfectly linear particle motion would have a value of 1.0. Eighty-eight percent of the located events had principal-axis contribution ratios exceeding 0.95 .

\section{Results}

Figure 7 shows the map view of the microearthquake source locations for the data collected over the 6-month monitoring period. One hundred twenty one events could be uniquely located within the traveltime-residual and particle-motion-linearity constraints defined above. Different symbols are used to group sets of source locations that align as planar or linear features. The grouping is based on the cross-section view (Figure 8) along the profile A-B of Figure 7. Source locations that fall into no particular group are shown with the cross symbols. A perspective view of the planes defined by the 4 spatially coherent hypocenter groups is shown in Figure 9. The axes of the planar volumes displayed in Figure 9 are determined by the eigenvectors which describe the principal axes fitting the spatial distribution of each groups' hypocenters. ${ }^{8}$ Dimensions of the planar volumes exclude $20 \%$ of the extreme outer event locations in each dimension so that outlying hypocenters do not affect the shape and size of the volume defined by the majority of events. The strike and dip of each plane was also determined from the eigenvector analysis and are summarized in Table 1. 

During Primary Oil Production, Clinton County, Kentucky

\begin{tabular}{|c|c|c|}
\hline $\begin{array}{c}\text { Hypocenter } \\
\text { Group }\end{array}$ & Strike & Dip \\
\hline Group 1 & $\mathrm{N} 65^{\circ} \mathrm{E}$ & $24^{\circ} \mathrm{NW}$ \\
\hline$\nabla$ Group 2 & $\mathrm{N} 61^{\circ} \mathrm{E}$ & $27^{\circ} \mathrm{NW}$ \\
\hline Group 3 & $\mathrm{N} 64^{\circ} \mathrm{E}$ & $34^{\circ} \mathrm{SE}$ \\
\hline$\square$ Group 4 & $\mathrm{N} 68^{\circ} \mathrm{E}$ & $20^{\circ} \mathrm{SE}$ \\
\hline
\end{tabular}

Table 1. Strike and dip of planes defined by eigenvector analysis of the 4 hypocenter clusters shown in Figures 7,8 and 9.

The low-angle planar features delineated by the hypocenters can be interpreted as a set of thrust faults striking approximately $\mathrm{N} 65^{\circ} \mathrm{E}$ (Figures 7,8 and 9 ). The most prominent fault, defined by group 1 (diamond symbols), dips to the NW at $24^{\circ}$ from the top of the High Bridge Group to the top of the Knox (Figure 8). reroups 3 and 4 (circle and square symbols, respectively) define 2 surfaces that are nearly co-planar and which dip to the SE at $34^{\circ}$ and $20^{\circ}$, respectively, antithetic to the main fault structure. Another minor fault, defined by group 2 (triangle symbols), dips to the $\mathrm{NW}$ at $27^{\circ}$, synthetic to the main fault.

The thrust fault interpretation is supported by a composite fault-plane solution computed using $\mathrm{P}$-wave polarities recorded on both geophone tools for all 109 clustered events (groups 1 to 4). In a composite fault-plane solution it is assumed that all the events have the same focal mechanism. Figure 10 shows the single, best-fit, fault-plane solution to all 218 first motion polarities on an equal-area, lower-hemisphere projection. ${ }^{9}$ A predominantly thrusting mechanism is indicated, and within the error of fit, a pure thrust mechanism can be accommodated. Twenty six observations are discrepant with the solution. The orientation of the prominent plane dipping to the northwest, delineated by group 1 (diamond symbols) in Figures 7 and 8 , is in good agreement with one of the computed fault planes (Figure 10).

The composite fault-plane solution pressure axis (p-axis) is oriented $\mathrm{N} 32^{\circ} \mathrm{W}$ (Figure 10). If the fault plane is the plane of maximum shear, then the p-axis is the direction of maximum principal stress. ${ }^{10}$ However, the fault motion will depend on the orientations of preexisting planes of weakness in addition to the contemporary stress field. P. axis orientations, therefore, do not place strong constraints on the maximum principal stress direction. The only restriction is that the maximum principal stress direction must lie in the quadrant containing the p-axis. " Maximum horizontal stress directions for the Appalachian basin are consistent with the ENE trend of the Midcontinent stress province. ${ }^{12,13}$ In Perry County of eastem Kentucky borehole breakout data indicate a maximum horizontal stress direction of $\mathrm{N}^{\prime} 1^{\circ} \mathrm{E}^{12}$. Stress orientation in western Kentucky is affected by the New Madrid seismic zone where the maximum horizontal stress orientation is rotated $20^{\circ}$ to $25^{\circ}$ clockwise from the Midcontinent trend. ${ }^{14}$ Borehole breakout data in Hopkins County of western Kentucky indicate a maximum horizontal stress orientation of $\mathrm{N} 81^{\circ} \mathrm{W} .{ }^{12} \mathrm{We}$ are not aware of any stress orientation data in the Clinton County area (south-central Kentucky). Maximum horizontal stress crientations in the study area may be transitional between the measured trends of eastern and western Kentucky. The strike of the microearthquake-location trends and the composite fault plane solution are consistent with the general NE-SW strike of structures in the Appalachian basin as well as the trend of local, surface-mapped geologic structures of the study area. ${ }^{15}$

During the 6-month period that the microseismic data were collected, significant volumes of fluid were being extracted in the monitor area only from the deviated well FS2 (a cumulative 11,000 bbls of oil). The original discovery well FSI discussed above, only produced an additional 200 bbls of oil during the second, 2-tool monitoring phase. Well MF2 showed significant potential for oil production with a tested initial production rate of 430 bbls per day at a true vertical depth (tvd) of $1270 \mathrm{ft}$ but was never put on-line, because high volumes of brine water produced at $1140 \mathrm{ft}$ tvd could not be effectively isolated. The remaining three production wells shown in Figures 7 , 8 and 9 (PD1, IW2 and IW4) only produced a cumulative volume of $2750 \mathrm{bbls}$ of oil, and less than $2 \%$ of this extraction occurred during the 6-month monitoring period. All the other wells, shown with open circles in Figure 7, were dry holes. The wells that produced significant volumes of oil in the study area or showed significant potential for oil production are projected on to the crosssection and perspective views (Figures 8 and 9, respectively). Except for FS1, production intervals of these wells (well bottoms) project onto, or close to, the projection of planes delineated by the microearthquake locations (Figure 8). However, none of the producing wells have been drilled into areas where the microseismicity 
occurred, that is, where the fractures along which slip occurred are known to exist (Figures 7 and 9). The 2 fractures revealed by groups 2 and 4 (triangle and square symbols of Figures 7,8 and 9) intersect the monitor well $M$. Well M was reportediy drilled in the late 1940's or early 1950 's, and records of the production history are not known to exist. The intersection of the upper fracture (group 2, triangle symbols) at about $875 \mathrm{ft}$ depth is corroborated with the density-derived porosity $\log$ from well $M$. The largest anomaly on the density log, over the depth interval 876 to $884 \mathrm{ft}$, indicates a porosity increases from a baseline value of $3 \%$ to $35 \%$. The only other large density anomalies correspond to lithologic variations (bentonite layers). Unfortunately, the density log was not run to $1200 \mathrm{ft}$ where the lower fracture intersects well $\mathrm{M}$.

\section{Discussion and Conclusions}

There are several reported cases of seismicity associated with fluid extraction on larger scales than this study. e.g. $16,17,18$ Segall $^{7}$ has computed porcelastic stress changes accompanying fluid withdrawal for a simple reservoir geometry that are qualitatively consistent with several observations of earthquakes associated with aged reservoirs in which reservoir pressures have declined by 10 's of MPa. Rock surrounding the reservoir, where no change in pore fluid content has occurred, can accumulate stress due to contraction of the reservoir accompanying fluid extraction. Similarly, stress perturbations will occur away from a fracture being drained due to contraction of the fracture opening. ${ }^{18}$ Shear-slip along drained fractures will be inhibited, because the effective stress loading will predominantly increase the normal load across the drained fracture. Fractures in a state of incipient failure and adjacent to a drained volume could slip if the induced stress changes are large enough to perturb the state of stress to the point of shear failure. If the observed microearthquakes are triggered by stress perturbations associated with drained fracture closure, then the microseismicity may be revealing undrained reservoir fractures.

The most significant result from this study has been the discovery of extensive (up to 0.15 square-miles), lowangle, thrust faults within the Ordovician reservoir interval. These low-angle features are not observed in the surface-exposed Mississippian section, which is separated from the Ordovician section by the Devonian unconformity. General relationships between the fractures/faults revealed by the microseismicity and oil occurrence have yet to be demonstrated in the study area. To date, no new wells have been drilled into the mapped fractures along which shear displacement was detected. Plans have been made to monitor other producing areas of Clinton County to determine whether microearthquake occurrence is widespread and is associated with production, in general. Knowledge of cause/effect relationships are important in understanding the relationship of fractures along which slip occurs to the state of stress, geologic structures and the occurrence and flow of oil. Currently, we do not know if the microearthquakes are induced by production. We have recently re-deployed a single geophone tool in the monitor well at $1100 \mathrm{ft}$ depth to determine if microseismicity rates will be reduced as production in the monitor area ceases. Comparison of daily production variations with the microseismic event rates (e.g. Figure 4) do not show any clear correlations nor do we expect them to. If the microearthquakes are induced by production, we would expect them to be due to the cumulative effective stress loading and stress perturbations accompanying reservoir pressure reduction. Discrete shear displacement will occur along a fracture when the threshold shear strength of the fracture is exceeded. The time when slippage occurs will depend on the initial state of stress and the rate and magnitude of induced shear stress changes. Daily production variations can be attributed primarily to production operations and wellbore conditions (e.g. pump performance, and paraffin accumulation) and do not reflect gross reservoir pressure conditiois away from the borehole. Measurements of reservoir pressure changes and the in-situ stress field are needed to quantitatively varify that the microearthquakes are triggered by stress changes accompanying production.

\section{Acknowledgment}

This work was conducted as a collaborative effor between Los Alamos National Laboratory, several independent oil companies, the Kentucky Geological Survey and the Clinton County Oil and Gas Advisory Committee under the auspices of the U.S. Department of Energy's Natural Gas and Oil Technology Partnership. Special thanks are extended to Jay Bertram of Polestar, Inc and Chairman of the Clinton County Oil and Gas Advisory Committee and James Drahovzal of the Kentucky Geological Survey for their efforts in initiating and supporting this collaborative project. We are also grateful to Hunt Perkins and David Earle of Petro-Hunt, Inc., Harvey Young of Harvey Young and Company, Bill Griffith of the Ohio Kentucky Corporation, and Neal Rudder of Ramco Energy Corporation for their participation in the present study. Several other individuals and companies active in the area contributed data and helpful discussions in the 
interest of this project, including: Michael Hanratty out of Grapevine, TX, Eddie Wallace of Touchwood Resources, Inc., Deborah Hannah of Hannah and Hannah, Howard Nevins of Trey Exploration, Inc., Stephen Schaefer of Polaris Energy, Ray Garton of Mammoth Geophysical, Inc., Lynn Wagoner of Ohio Kentucky Corp., and Jesse Kincheloe out of Campbellsville, KY. We also thank Frank Summers for allowing us to place monitoring equipment on his land.

\section{References}

1. Hamilton-Smith, T., B.C. Nuttall, P.J. Gooding, D. Walker, and J.A. Drahovzal, "High-volume oil discovery in Clinton County, Kentucky," Kentucky Geological Survey, Series 11, Information Circular 33, 1990.

2. Goodings, P.J., "Study of the unconformity of the Knox Group in the subsurface of south-central Kentucky," M.S. thesis, Eastem Kentucky University, Richmond, Ky, 212 p., 1983.

3. Conant, L.C., and V.E. Swanson, "Chattanooga Shale and related rocks of central Tennessee and nearby areas," U.S. Geological Survey Professional Paper 357, 91 p., 1961.

4. Hamilton-Smith, T., P. H. Lowry, and R. M. Peterson, "Effects of the Acadian orogeny in the central Appalachian Basin: evidence for a three-plate tectonic model," Geol. Soc. Am. Abstracts with Programs, 21, 20, 1989.

5. Goodings, P.J., G.L. Kuhnhenn, and J.D. Kiefer, "Depositional environments and reservoir characteristics of the Lower Ordovician Knox Group and the Middle Ordovician Wells Creek Dolomite and High Bridge Group, Cumberland County, south-central Kentucky," In Smosna, R. (ed.), A walk through the Paleozoic of the Appalachian Basin, A.A.P.G. Eastem Section Mtg., Core Workshop Guidebook, 19-29, 1988.

6. Fehler, M., L. House, and H. Kaieda, "Seismic monitoring of hydraulic fracturing: Techniques for determining fluid flow paths and state of stress away from a wellbore," In Proc. 27th U.S. Symposium on Rock Mechanics, Tuscaloosa, Alabama, June 23-25, 1986.

7. Segall, P., "Earthquakes triggered by fluid extraction," Geology, 17, 942-946, 1989.

8. Flynn, E.A., "Signal analysis using rectilinearity and direction of particle motion," Proc. I.E.E.E., 53, 1725 1743, 1965.
9. Reasenberg, P. and D. Oppenheimer, "FPFIT, FPPLOT and FPPAGE: Fortran computer programs for calculating and displaying earthquake fault-plane solutions," U.S. Geological Survey, Open-File Report 850739, 1985.

10. Aki, K. and P.G. Richards, "Quantitative seismology, theory and methods, volume 1," W.H. Freeman and Co., 1980.

11. McKenzie, D.P., "The relationship between fault plane solutions for earthquakes and the directions of the principle stresses," Bull. Seism. Soc. Am., 59, 591-601, 1969.

12. Plumb, R.A., and J.W. Cox, "Stress direction in eastem North America determined to $4.5 \mathrm{~km}$ from borehole elongation measurements," J. Geophys. Res., 92, 48054816, 1987.

13. Evans, K.F., "Appalachian stress study 3. Regional scale stress variations and their relation to structure and contemporary tectonics," J. Geophys. Res., 94, 17619. $17645,1989$.

14. Zoback, M.L., "Stress field constraints of intraplate seismicity in eastem North America," J. Geophys. Res., 97, 11761-11782, 1992.

15. Lewis, R.Q., and R.E. Thaden, "Gcologic map of the Wolf Creek Dam quadrangle, Kentucky," U.S. Geological Survey Map GQ-177, 1962.

16. Pennington, W.D., S.D. Davis, S.M. Carlson, J. Dupree, and T.E. Ewing, "The evolution of seismic barriers and asperities caused by the depressuring of fault planes in oil and gas fields of South Texas," Bull. Seism. Soc. Am., 76, 939-948, 1986.

17. Grasso, J.R., and G. Wittlinger, "Ten years of seismic monitoring over a gas field," Bull. Seism. Soc. Am., 80, 450-473, 1990.

18. Doser, D.I., M.R. Baker, and D.B. Mason, "Seismicity in the War-Wink gas field, Delaware Basin, Texas, and its relationship to petroleum production," Bull. Seism. Soc. Am., 81, 971-986, 1991.

19. Pollard, D.D., and Segall, P., "Theoretical displacements and stresses near fractures in rocks: with applications to faults, joints, veins, dikes, and solution surfaces," In Atkinson, B.K. (ed.), Fracture mechanics of rock, Academic Press, 1987 


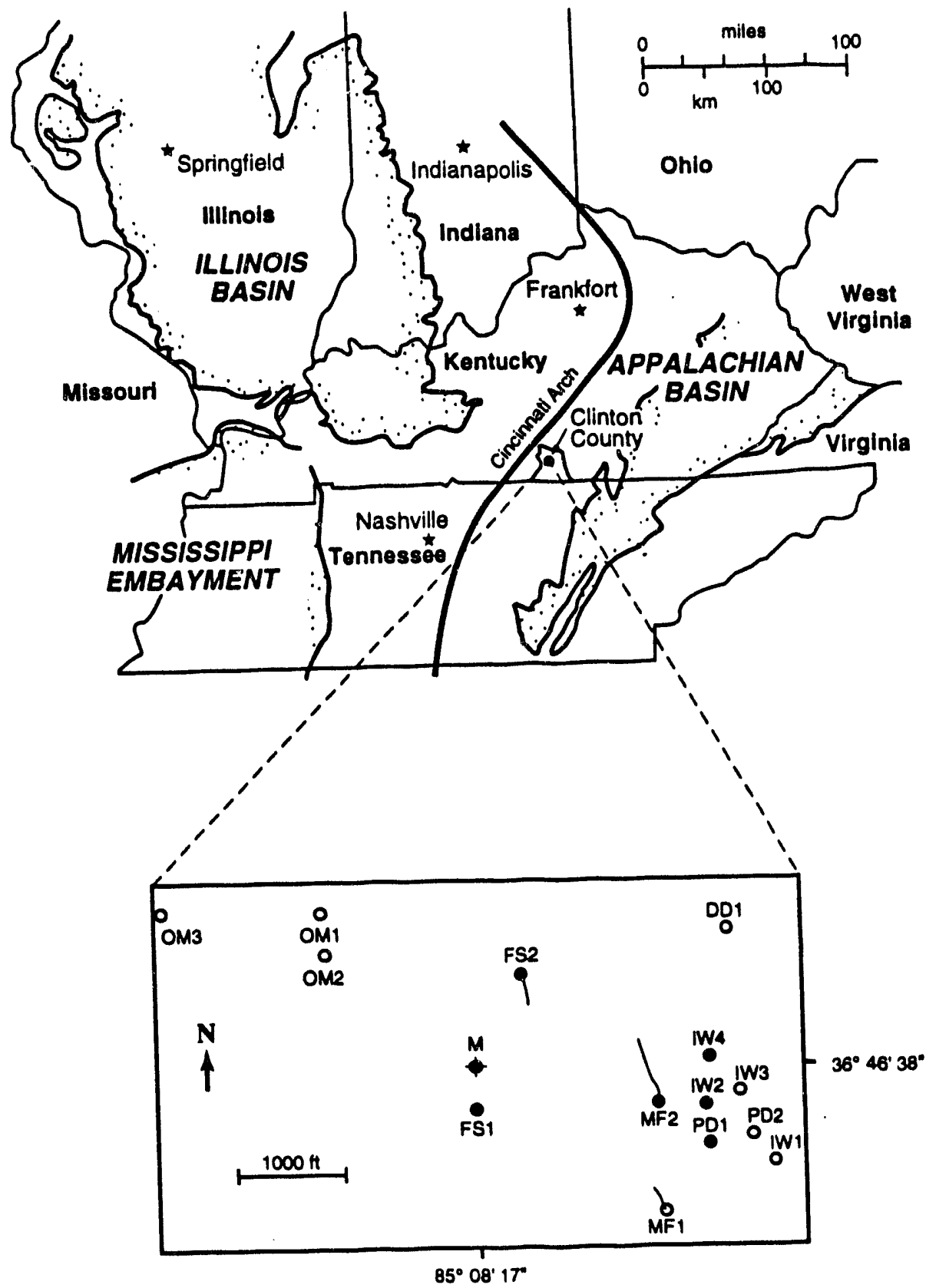

Figure 1. Map of the study area. $M=$ monitor well. Solid circles show production wells. Open circles show dry wells. Traces show trajectories of deviated wells FS2, MF1 and MF2. 


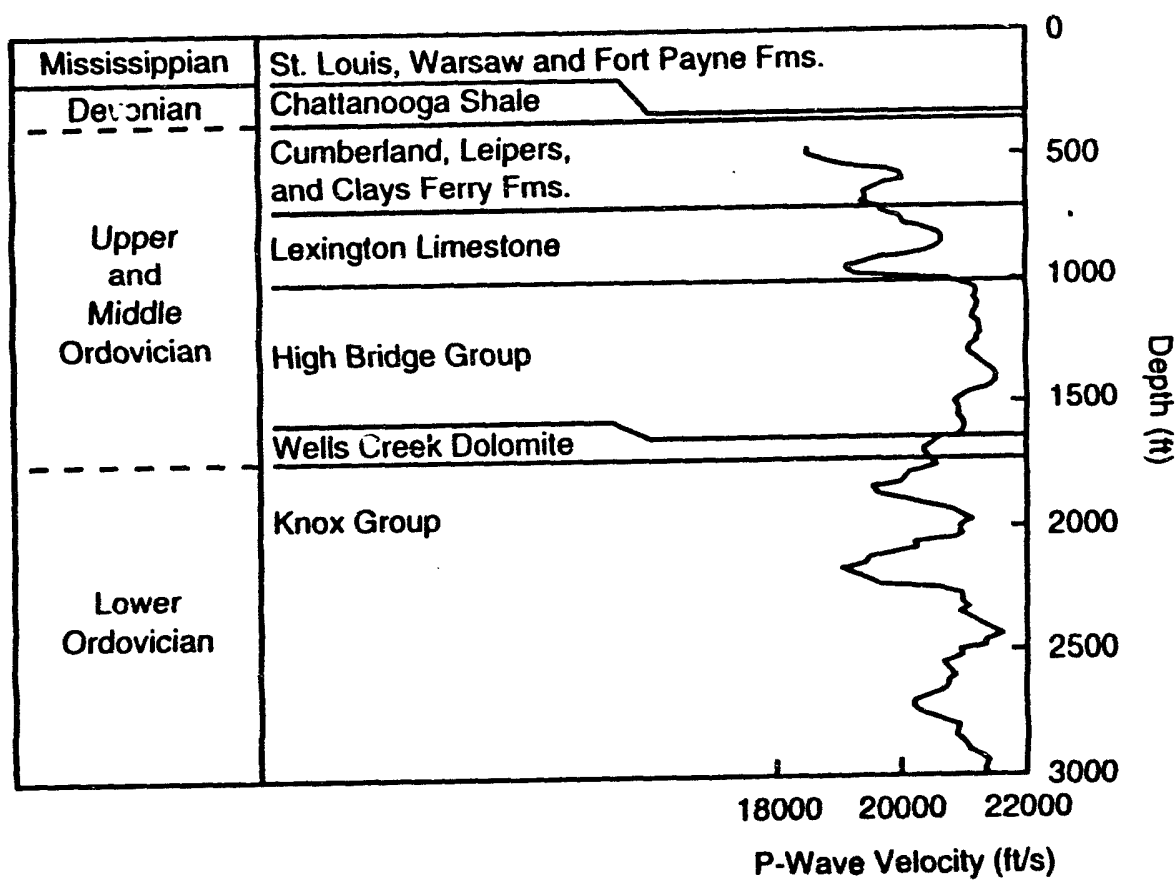

Figure 2. Geologic section and the sonic-log-derived P-wave velocity structure correlated to the monitor well $\mathrm{M}$. The monitor well total depth is $1240 \mathrm{ft}$. The top of the Knox Group was corrclated from well DD1 (Figure 1). Depths of the Devonian and Ordovician unconformities are shown with dashed lines on the left The P-wave velocity structure was derived from a composite of sonic logs from the Clinton County area. The composite sonic log was smoothed by computing median values over a $100 \mathrm{ft}$ moving window and was then decimated at $20 \mathrm{ft}$ intervals. Microearthquake locations were determined using the resultant velocity structure.

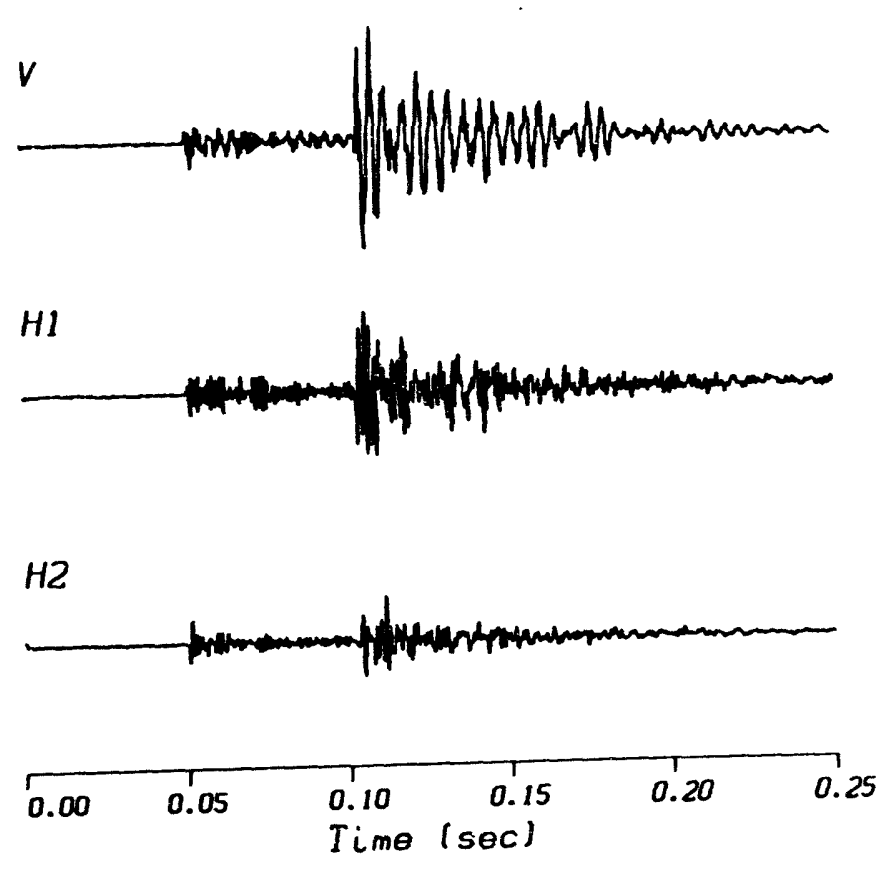

Figure 3. An example of the waveforms of a microcarthquake recorded on the 3-component, borchole geophone during the initial monitoring test. $\mathrm{V}$ marks the vertical component, $\mathrm{Hl}$ and H2 mark the 2 horizontal components. The P-wave arrives at about $0.05 \mathrm{sec}$. The $S$-wave arrives at about $0.10 \mathrm{sec}$. 

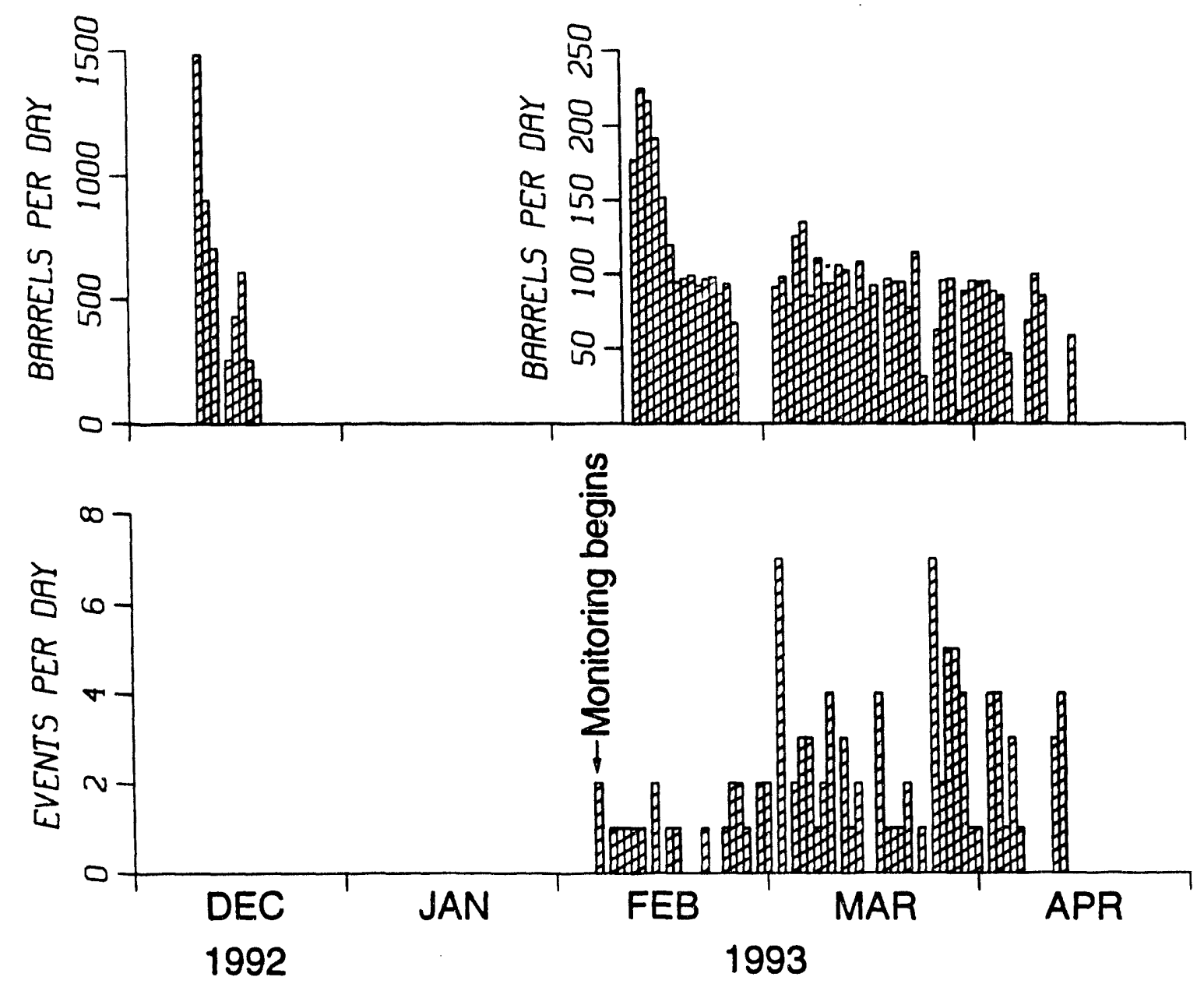

Figure 4. Histogram comparing the daily production from well FS1 (above) with the daily microearthquake event count (below) during the initial, single-geophone-tool monitoring test. Of the total production shown, $51 \%$ was extracted during the first 9 days of production in mid-December, 1992. The well was then shut in for completion. Production then resumed in February (note the production scale change) 6 days after monitoring began. 


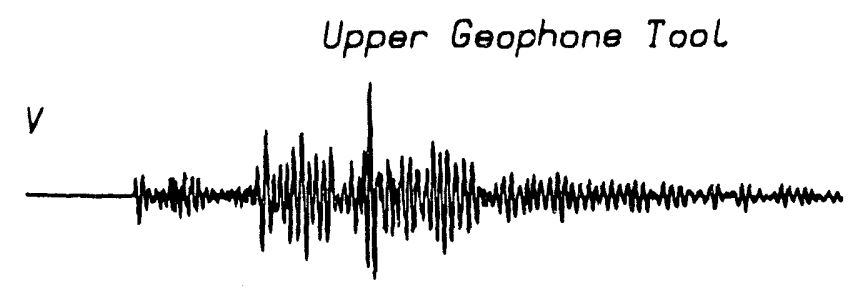

HI

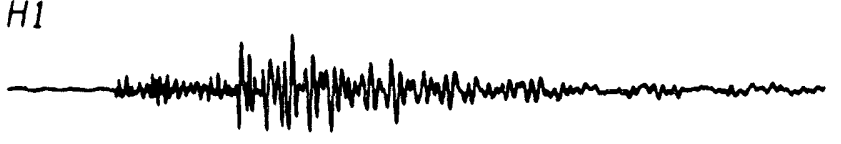

H2

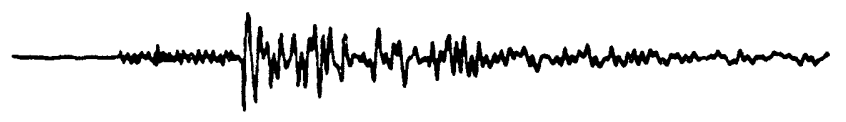

0.1 $0.2 \quad 0.3$

Iime (sec)

Lower Geophone Tool

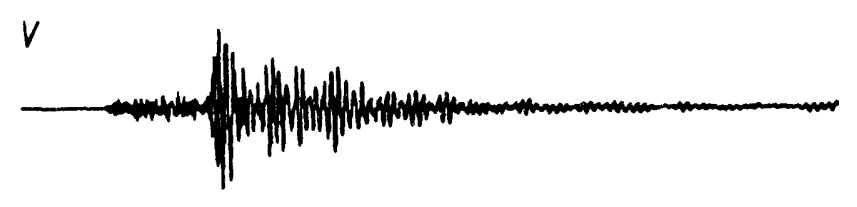

HI
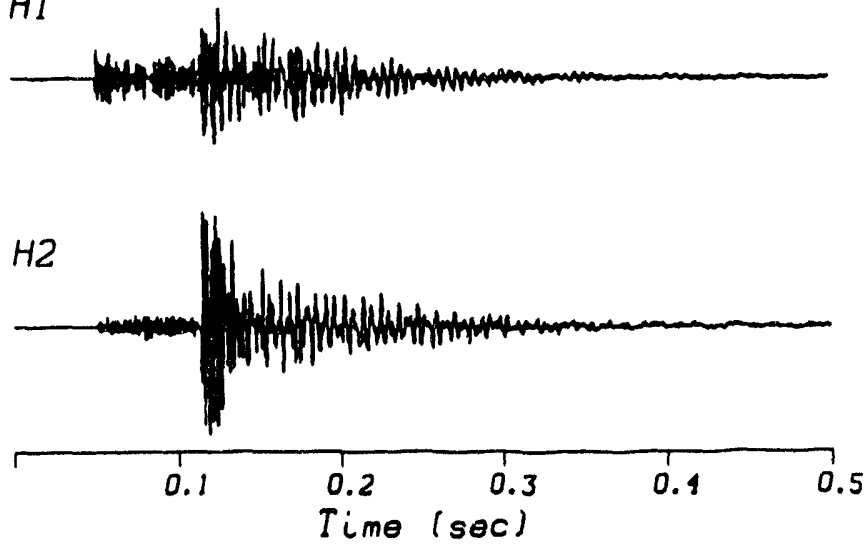

Figure 5. An example of the waveforms of a microearthquake recorded on both geophone tools during the 2 -station deployment.

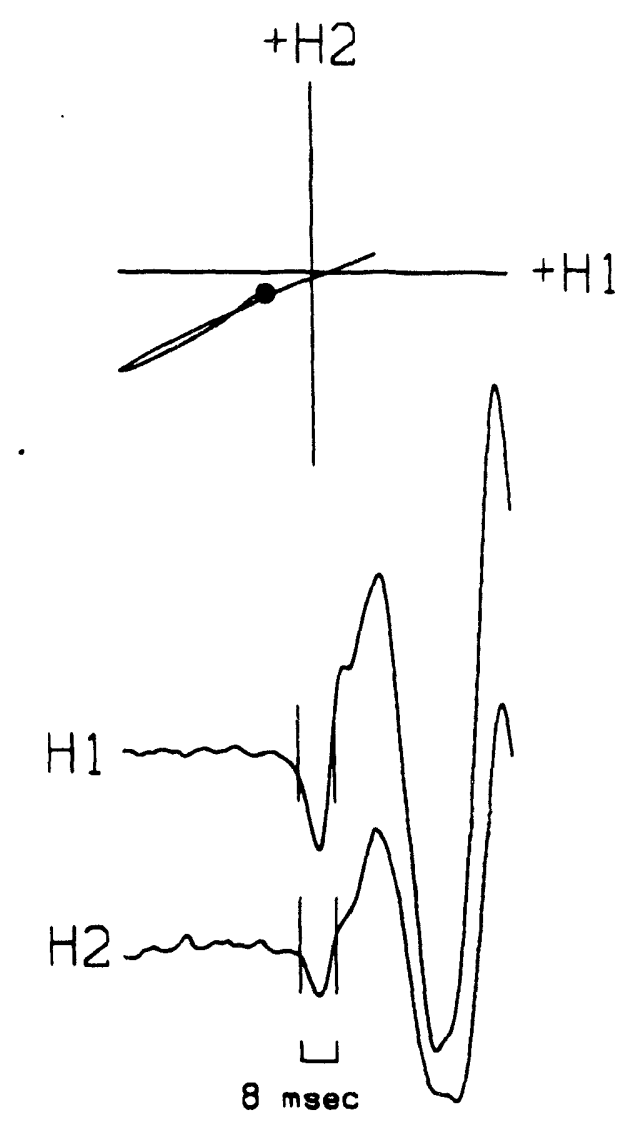

Figure 6. First-break motions recorded on the 2 horizontal components of the lower tool at $1100 \mathrm{ft}$ depth (below) and the particle motion projection (hodogram, shown above) for an orientation shot fired in a shallow hole $800 \mathrm{ft}$ from the monitor well. The hodogram plot shows the particle motion for the $8 \mathrm{msec}$ data window marked on the seismograms. 


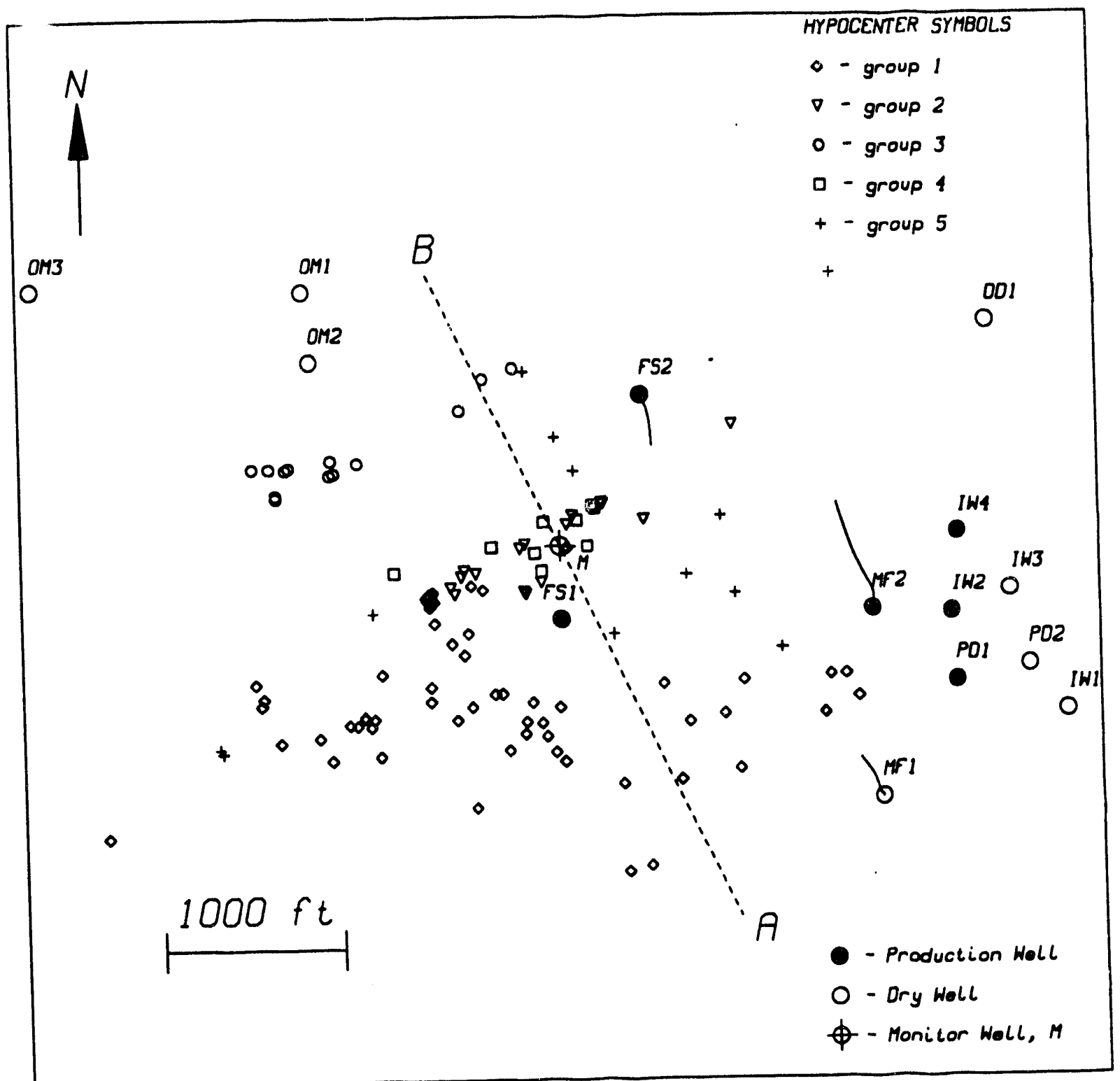

Figure 7. Map view of microcarthquake hypocenters. 


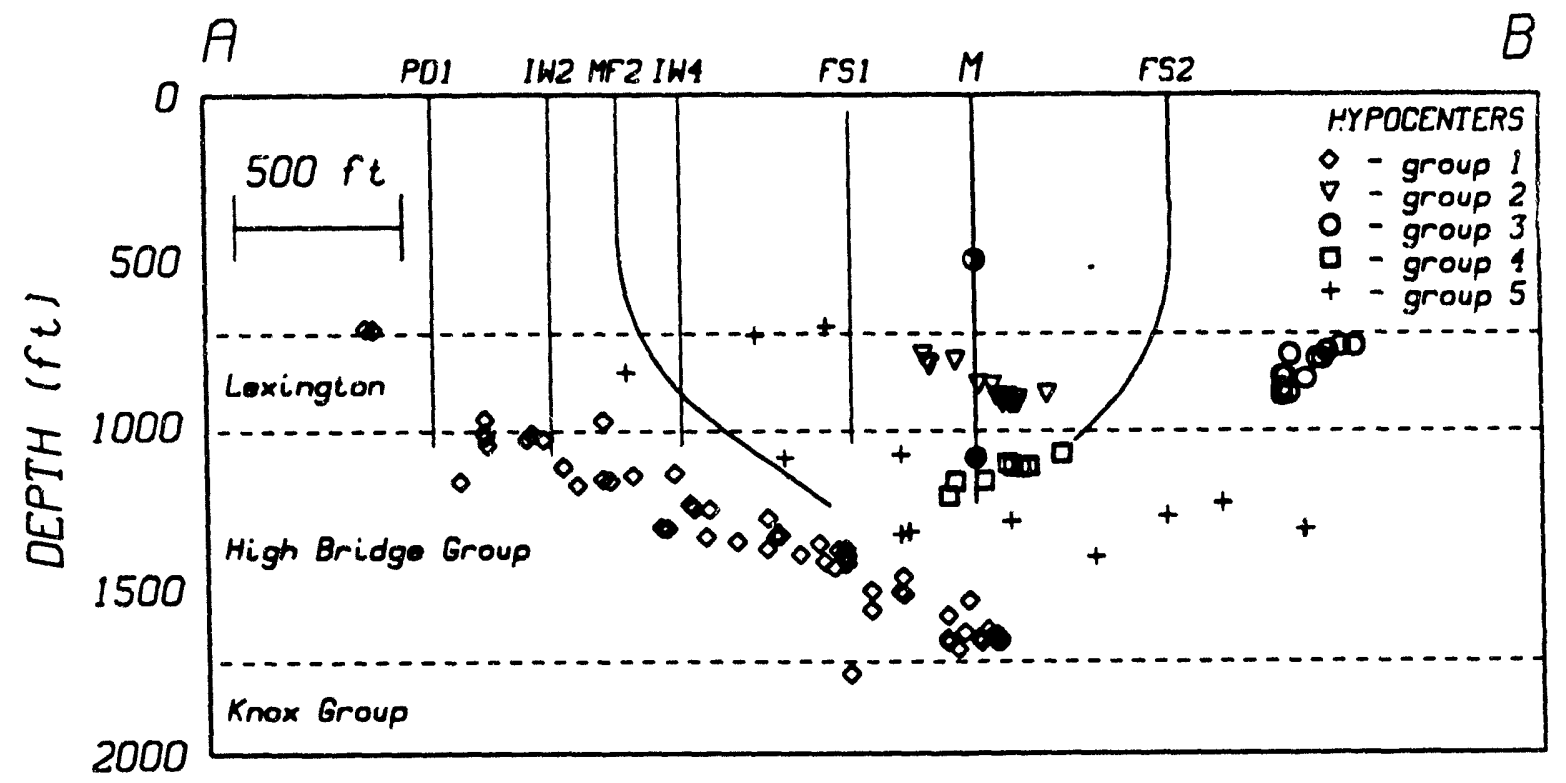

Figure 8. Depth-section projection of hypocenters along profile A-B of Figure 7. Projection of production welis are also shown. Geophone tool locations are shown as solid dots along well M. Source locations that fall in no particular cluster are shown with the cross symbols (group 5). No vertical exaggeration. 


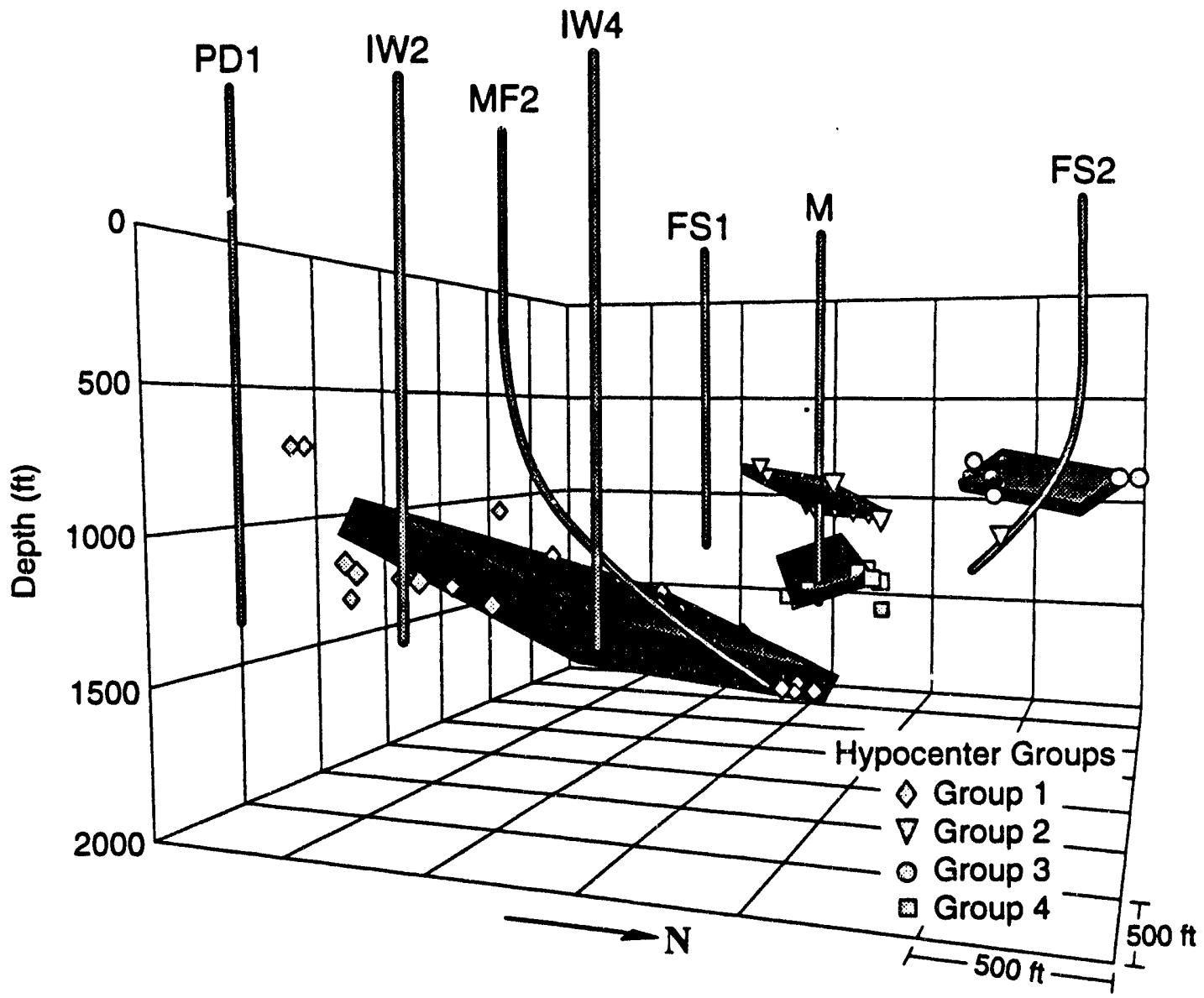

Figure 9. A perspective view of the fracture planes defined by hypocenter groups 1 through 4 . The axes of the planar volumes are determined by the eigenvectors which describe the principal axes fitung the spatial distribution of each groups' hypocenters. Dimensions of the planar volume exclude $20 \%$ of the extreme outer event locations in each dimension so that outlying hypocenters do not affect the shape and size of the volumes defined by the majority of events. Hypocenters outside or near the defined boundaries of the planes are also displayed. 


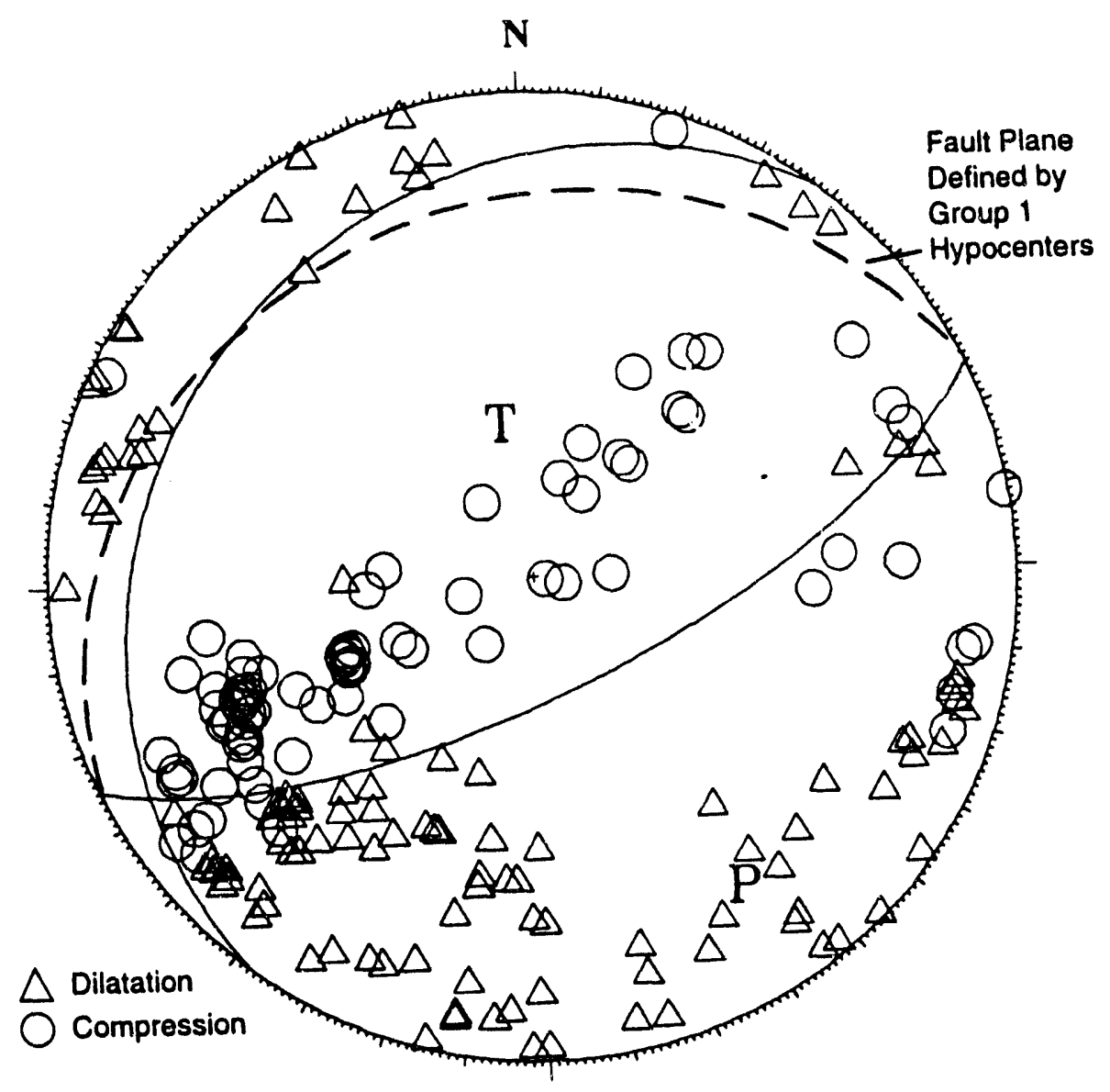

Figure 10. Composite fault-plane solution computed using P-wave polarities recorded on both geophones for the 109 clustered hypocenter events ( 218 first motion polarities). The fault plane defined by the hypocenters of group 1 (diamond symbols of Figures 7,8 and 9) is shown with the dashed curve. $P$ and $T$ mark the pressure and tension axes, respectively. 

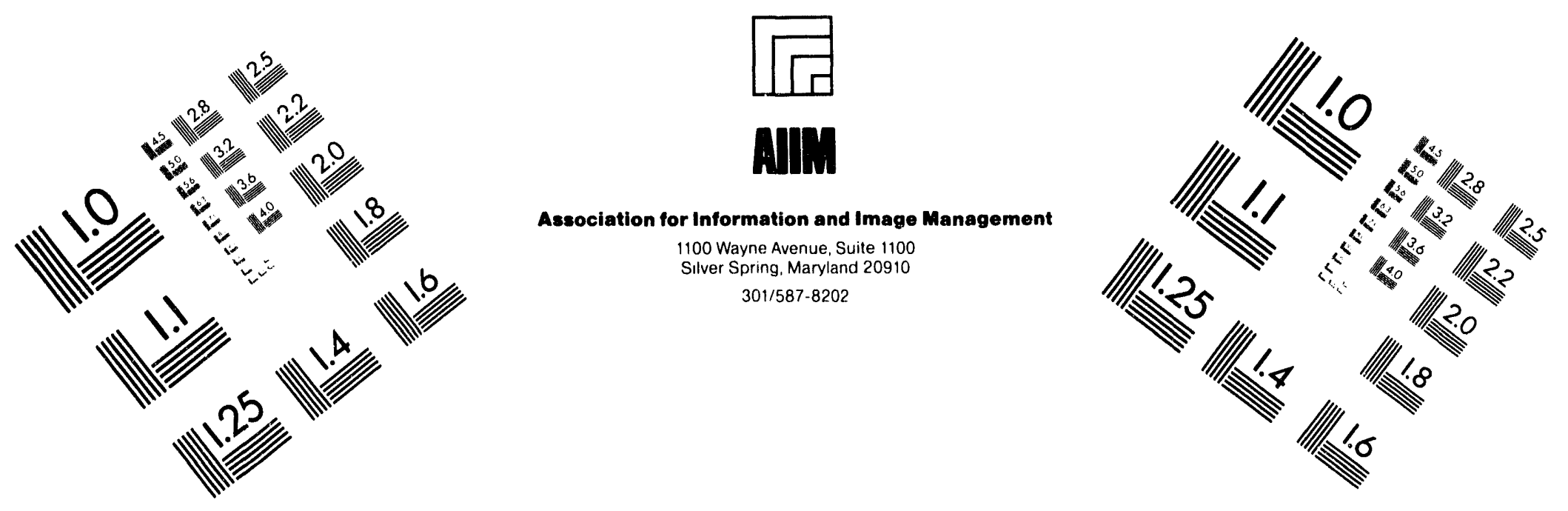

\section{Centimeter}

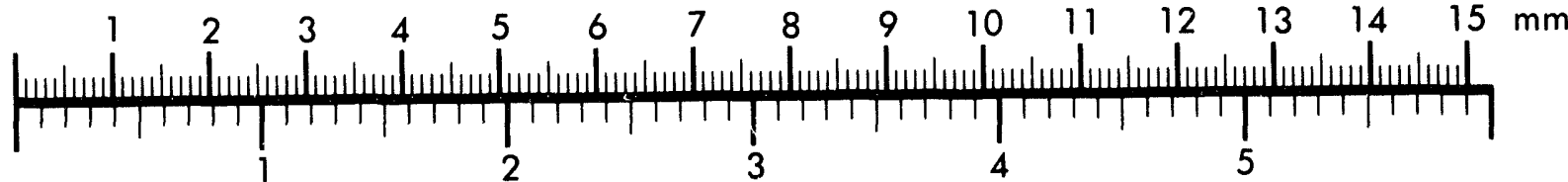

Inches
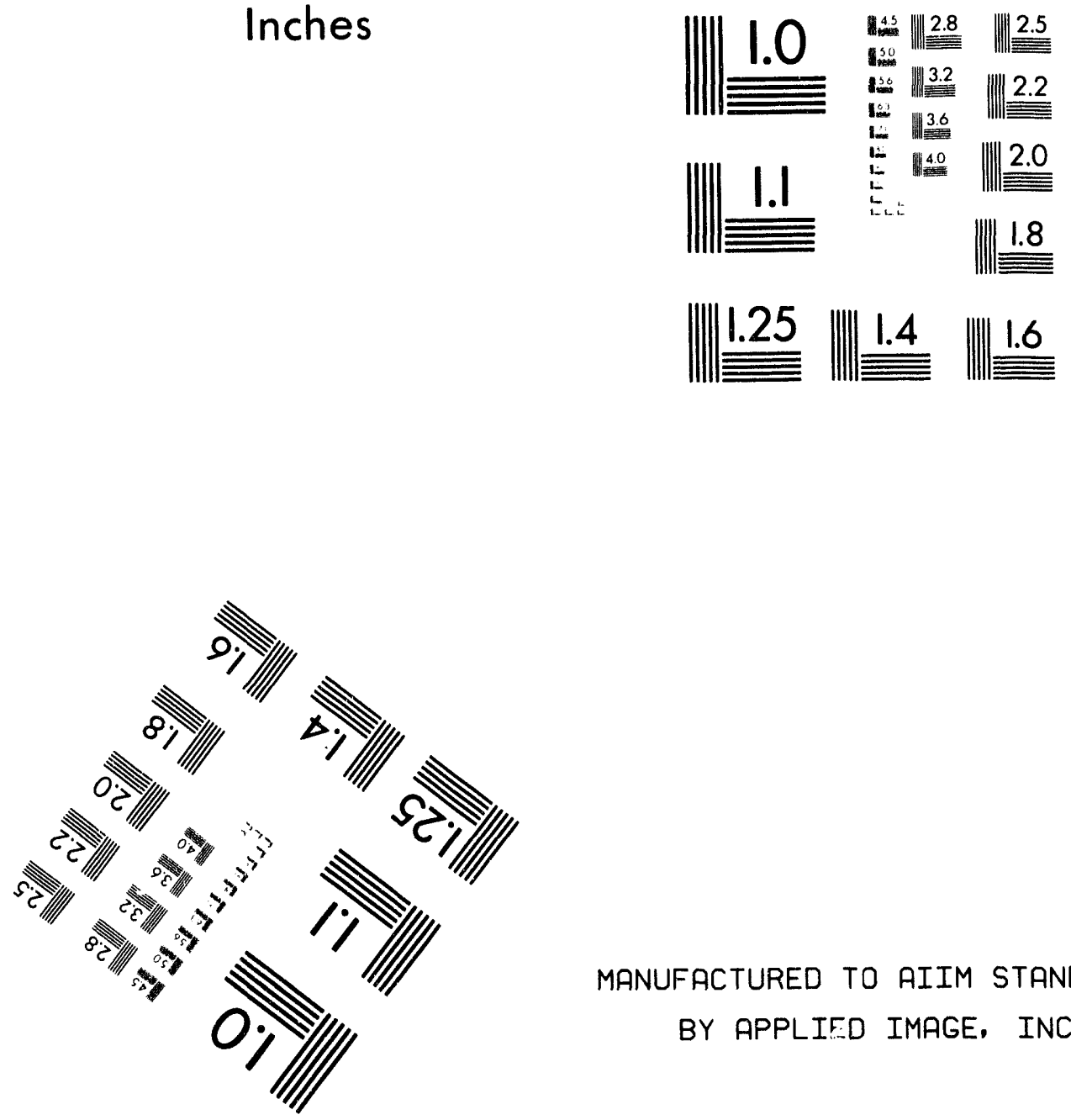

MANUFACTURED TO AIIM STANDARDS

BY APPLIFD IMAGE, INC.

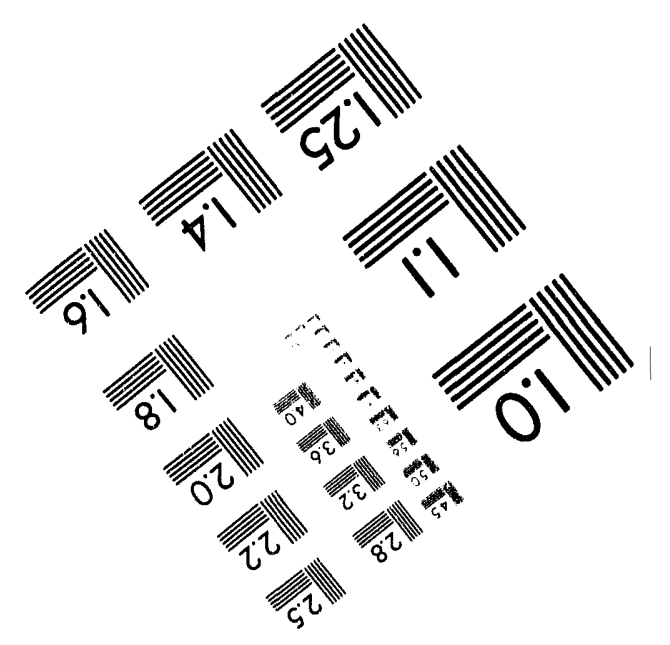




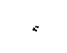



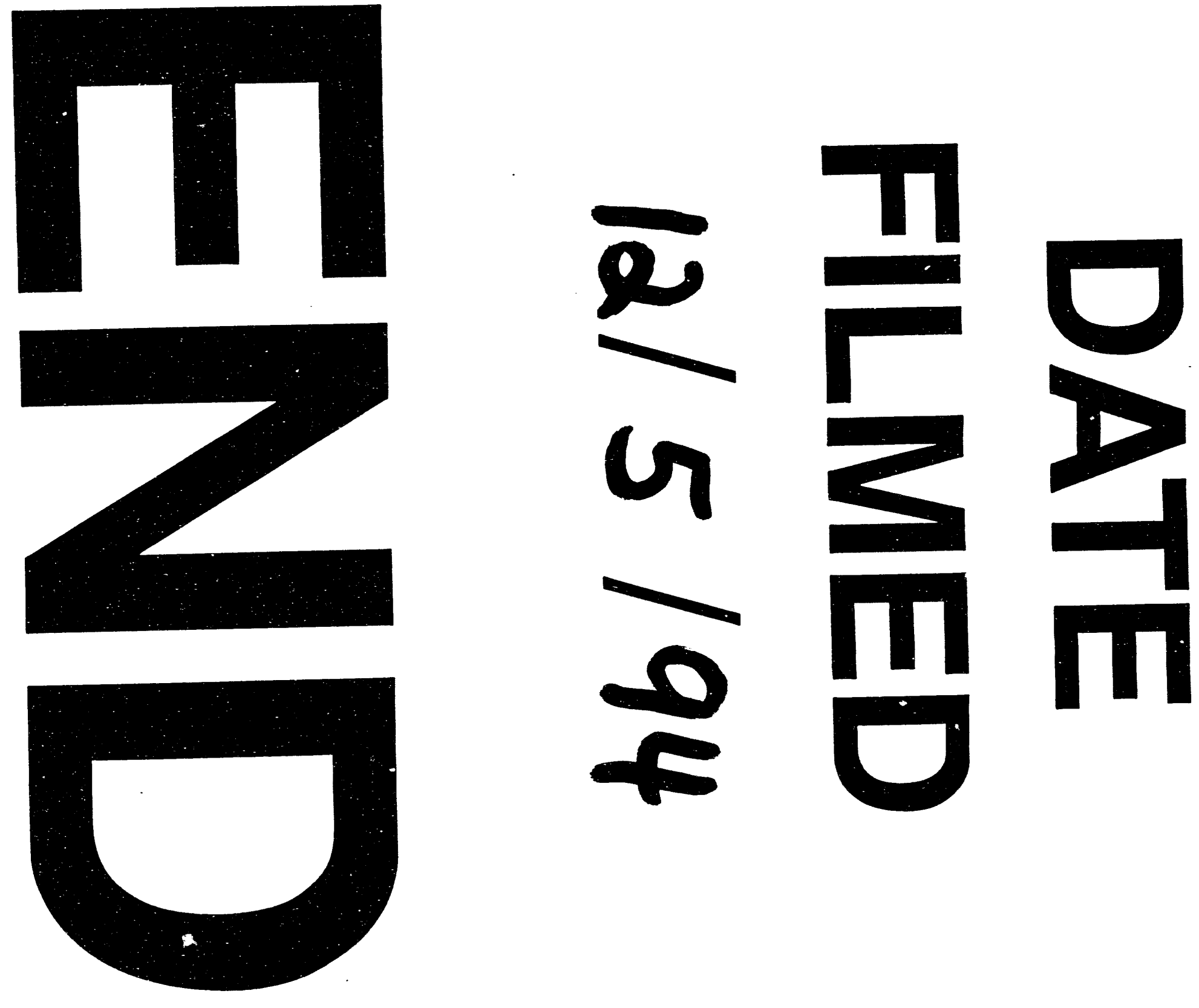